\title{
Impact and Adaptation to Cyclone AlLA: Focus on Water Supply, Sanitation and Health of Rural Coastal Community in the South West Coastal Region of Bangladesh
}

\author{
Tapos Kumar Chakraborty ${ }^{*}$, A. H. M. Enamul Kabir, Gopal Chandra Ghosh \\ Department of Environmental Science and Technology, Jessore University of Science and Technology, Jessore, Bangladesh \\ Email address: \\ taposchakraborty@rocketmail.com (T. K. Chakraborty), shimul.enamul778@gmail.com (A. H. M. E. Kabir), \\ gopales8@hotmail.com (G. C. Ghosh) \\ ${ }^{*}$ Corresponding author
}

\section{To cite this article:}

Tapos Kumar Chakraborty, A. H. M. Enamul Kabir, Gopal Chandra Ghosh. Impact and Adaptation to Cyclone AILA: Focus on Water Supply, Sanitation and Health of Rural Coastal Community in the South West Coastal Region of Bangladesh. Journal of Health and Environmental Research. Vol. 2, No. 3, 2016, pp. 13-19. doi: 10.11648/j.jher.20160203.11

Received: July 18, 2016; Accepted: August 29, 2016; Published: September 30, 2016

\begin{abstract}
The objective of these study was to examine the impact of cyclone AILA on water supply, sanitation and health status in the southwest coastal region of Bangladesh and explore adaptation strategies. This study relied on field investigation where 120 respondents answers were collected randomly from three disasters prone unions in coastal Bangladesh through a defined questionnaire. Natural disaster was a common feature of the study area. The cyclone AILA hit the southwestern coastal region of the country in $25^{\text {th }}$ May 2009. Water supply and sanitation condition became harshly disrupted during that time when it embraced various water borne diseases. Qualitative field data represented that about $67 \%$ people faced serious drinking water scarcity, especially during disasters and summer season due to the disruption of water supply facilities. In the study area, $97 \%$ households sanitation system were totally destroyed and $96 \%$ households could not use their sanitation facilities during disasters, unattainable sanitation technology was the main causes of these damage. Owing to poor water supply and sanitation facilities, people suffered from diarrhoea (32\%) and dysentery (44\%) diseases during the study conducted time. Tube-wells and latrines are build on an elevated base with improved floor and the excavation of ponds for salinity removal is the main adaptation approach for this area. Results drawn from this research and recommended adaptation strategies will be useful for local and national level planners, as well as international donors for preparing future disaster risk reduction plan.
\end{abstract}

Keywords: Coastal Bangladesh, Health, Cyclone AILA, Sanitation, Water Supply

\section{Introduction}

Bangladesh is one of the most vulnerable countries to natural disasters impact in the world [1]. The coastal area of Bangladesh is situated in the south of the country, it is 710 $\mathrm{km}$ and the coastal area comprises $36,500 \mathrm{~km}^{2}$ with a population of 35 million and coastal urban population is 8.2 million [2]. The coastal region of Bangladesh is familiar as a tremendously vulnerable part [3]. Bangladesh's high susceptibility to climate change for its hydro-geological and socioeconomic factors such as topographical position, flat deltaic landscape with very low elevation, extreme climate variability and high population density and poverty incidence. Despite the recent paces towards achieving sustainable development, Bangladesh's potential to sustain its development is faced with significant challenges posed by climate change [4].

Many projected climate change impacts, including sea level rise, temperature increase, heavy rainfall, drought and cyclone intensity would increase yearly flooding, river bank erosion, salinity intrusion, etc. that already poses a serious impediment to the economic development of Bangladesh [5]. The coastal area of Bangladesh and the Bay of Bengal are located at the tip of the northern Indian Ocean, which is frequently hit by severe cyclonic storms, generating long tidal waves that are aggravated by the shallow bay [6]. At least one major tropical cyclone strikes the Bangladesh coast each year $[7,8]$ with powerful tidal surges that impact 
hundreds of thousands of lives and make it more unsafe than many other regions of the world [9].In addition to Cyclone Aila in 2009, the southeast coast was also affected by Cyclone Bijli in April. In October 2008, the southwest coast was hit by Cyclone Rashmi, and in November of the same year Cyclone Sidr, it's the country almost every year [10]. Cyclone Aila took shape on 23rd May 2009 and hit the South-Western coastal zone of Bangladesh on 25th May 2009. The wind speed of the Aila was about 104.6-120.7 $\mathrm{km} / \mathrm{h}$ [3]. Furthermore, the damage to embankments extended to an area of $1743 \mathrm{~km}$ which is one of the main causes of a serious secondary disaster of widespread and prolonged post-cyclone inundation in the broken polders [11].

Almost 2.3 million people were affected by Aila and many people were stranded in flooded villages. The height of the tidal surge was about $10-13 \mathrm{~m}$ and it washed away the enormous number of households, lives, livestock, crops and all other resources of the affected region. This whole incident happened within a very short period of time, and then people became homeless leaving their assets in the households. During the cyclonic event a very small percentage of the affected people could manage to take shelter in the nearby cyclone shelter and maximum people take shelter on roads and roofs of the schools, colleges, madrashas, mosques and Union Parisahd (local government) buildings. The Aila furiously hit the Satkhira and Khulna Districts of Bangladesh, caused the immediate death of about 325 people with massive infrastructure damages [3]. The Water Supply Sanitation and Hygiene (WASH) sector assessment, carried out during May and June 2009, found that some 4,000 protected ponds, 1,000 pond-sand filters, and 13,000 tubewells were damaged. This damage has adversely affected water supply coverage by 50 percent. In addition, over 210,000 household latrines were fully or partially damaged, accounting for 32 percent of the total sanitation coverage in the Satkhira and Khulna districts [12].

In Bangladesh 80 percent diseases are related to inadequate water supply and sanitation. As water supply and sanitation are severely affected by cyclone and flood, the risk of spreading of water borne and fatal diseases increase during disaster period [13]. In study area the literacy rates among the three unions are Burigoalini (38.93\%), Padmapakur $(37.08 \%)$ and Gabura (31.40\%). Sources of drinking water were tube well $(35.94 \%)$, tap $(6.46 \%)$, pond $(50.74 \%)$ and others $(6.86 \%)[14,15,16]$.

As Bangladesh is already extremely densely settled, relocation of coastal people in inland region is not possible. Indeed, many landless households from in lands have now migrated to the coast and settle in new created char lands (government-lands) which are heavily exposed to the devastation during cyclones. The vulnerability of this region is increasing due to lack of proper management. So, local level management is of utmost priority to mitigate the adverse impact of natural disasters. Planning and construction of relevant infrastructure will be the foremost important task of those initiatives. Exploring the existing situation is the prime tasks to start up any planning process. Therefore, this paper is an important initiative to assess the existing status of coastal communities. The main objective of this study is to explore the impact of natural disasters on water supply, health and sanitation problem of coastal community and an attempt to reduce the impact of natural disasters through adaptation mechanism.

\section{Study Area and Methodology}

The study has been conducted among Burigoalini, Padmapakur and Gabura Union ${ }^{1}$ of Shyamnagor Upazila ${ }^{2}$ in Satkhira district ${ }^{3}$ (see Fig. 1.). It is the last settlement areas in southern coast. People are mostly dependent on the resources of Sundarbans. Fishing, agriculture and non-agricultural laborers are widely practiced occupation in this community. A total of 37666 numbers of people lives in an area of 41 sq. $\mathrm{km}$. and all of them were affected by cyclone Aila and in the aftermath of the cyclone by water-logging.

The research is based on quantitative data and it was collected through household questionnaire survey. The questionnaire concentrated on the respondent drinking water source, sanitation facilities and health status of pre, during and post cyclone AILA. Some data has been collected through self-observation in order to know the actual status of these regions. 'Microsoft Office Excel 2010' programme was used to analyze the data. The total sample size of the household questionnaire survey was 120 . From the selected household list, 120 semi-structured and open-ended questionnaires were administered randomly among household heads, who were permanent resident because they have a vast knowledge and experience regarding the impact of disaster on various sectors. Samples were collected from three unions during October 2012 to December 2012.

\section{Results and Discussion}

\subsection{Impact and Adaptation Related to Drinking Water Supply}

Safe water scarcity is a cumulative problem in the coastal region of Bangladesh as it is revolving saline water slowly. Various types of natural disasters like poor rainfall, cyclone and storm surge, flood, etc. are making the situation worse. Coastal people gradually depend on ground water due to surface water salinity as a result ground water extraction are increasing day by day, for this reason the shallow aquifer has also been contaminated by salinity intrusion.Shymnagor upazilla is one of the disaster prone areas in the southwest coastal region of Bangladesh, where safe water scarcity is increasing day by day. According to World Health

\footnotetext{
1 Union is the third lowest tier of an official administrative unit of local government in Bangladesh.

2 The upazilla are the second lowest tier of the administrative unit of local government in Bangladesh.

3 The Districts are the first tier of the administrative unit of local government in Bangladesh.
} 
Organization [17], 70 million people of Bangladesh are exposed to drinking water which does not comply with the standards of the WHO. Mainly rural living people faced various types of problem such as the serious level of poverty, lack of safe and hygienic drinking water, etc. regular flooding and cyclone are identified as the main reason for these types of problems [18]. Various types of health risk are associated with water. Mainly coastal community became victim of these problems.

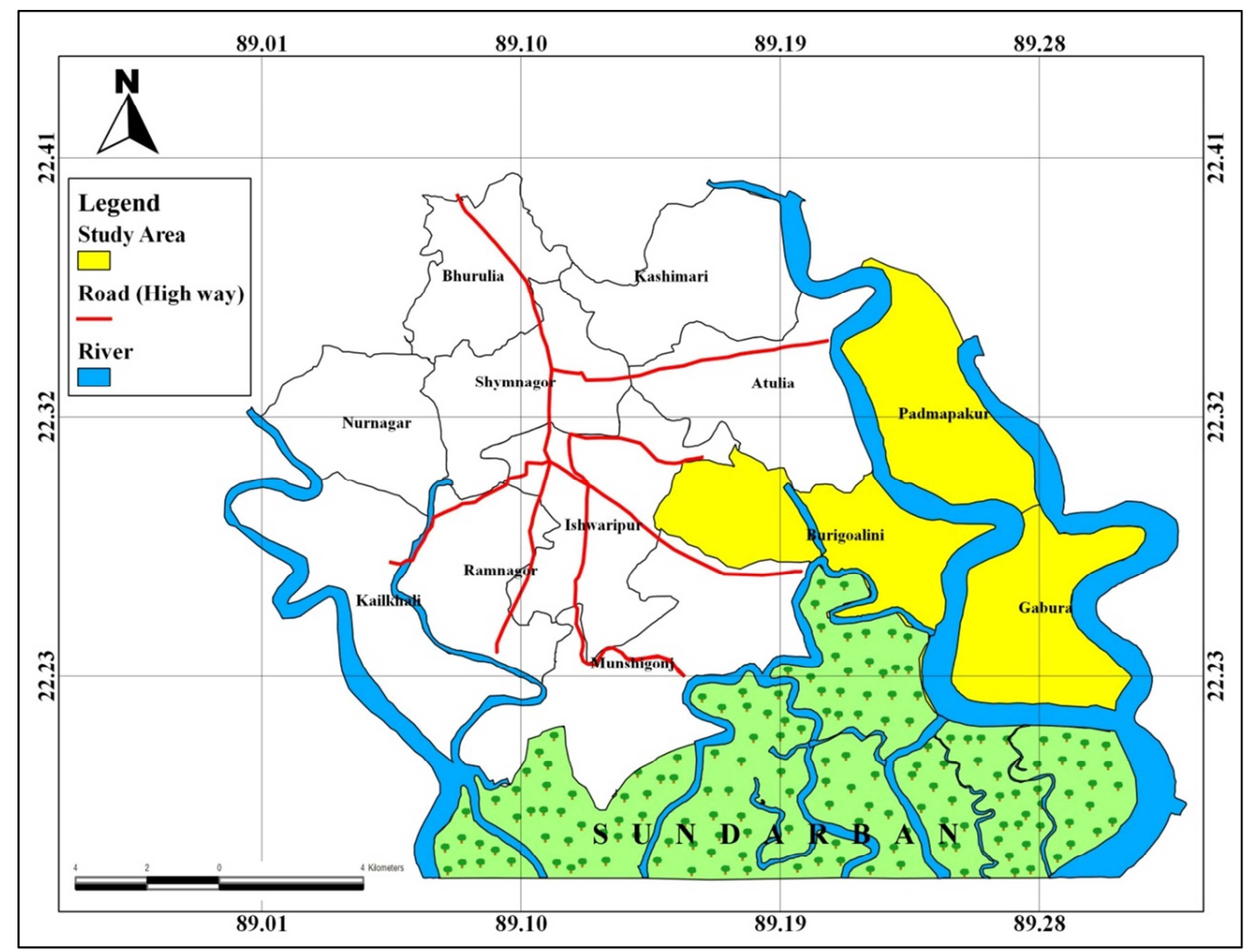

Figure 1. Map of selected study area (Shymnagor Upazilla of Satkhira district in Bangladesh).

\subsection{Impact on Drinking Water Supply}

In coastal area the sources of drinking water are destructed by geographical disadvantage and regularly facing natural disasters (e. g. River erosion, water logging, floods, cyclones and tidal surges etc.). In addition, the effects of climate change have caused hazards in this region to occur more frequently than before with greater intensity [19].

Shyamnagar was the victim upazilla, where most of the drinking water sources were damaged during cyclone AILA. The main drinking water sources were ponds $48 \%$, tube well $33 \%$, Pond Sand Filters (PSF) 15\% and rainwater harvesting $4 \%$ (Presented in Table -1). These water sources were generally affected by following reason:

- Inundation of water sources by contaminated flood water.

- Saline water intrusion.

- Disruption of access to safe water resources.

- Disrupting the infrastructures of water supply system.

From the field survey, it has been observed that during cyclone AILA, the drinking water supply option were NonGovernment Organization (NGO) or Voluntary organization supply water $(59 \%)$, collected from neighbor village $(28 \%)$ and used affected water source 13\% (Present in Table - 1) and about $67 \%$, household said that they are not getting adequate water for drinking and household activities during any types of natural disasters (Fig. 2) becaue all of the drinking water sources (ponds and tube wells) were destroyed by cyclone AILA. High tide surges contaminated all fresh water sources with pollute water and saline water that time people received the highest amount of drinking water shortage and most of the people used pollute water for drinking and cooking purpose because they do not have any other option. The sea level of this region is rising and it creates new salinity affected areas, which creates further scarcity of drinking water [20].

\subsubsection{Adaptation Measure Regarding Drinking Water Supply}

Following adaptation measures are required for combatting any types of natural disaster in case of drinking water source protection:

1. Adaptation measure for tube well.

- Fix tube well on high ground so that it does not 
inundated by floodwater.

- Keep surrounding clean.

- Cementing the base so that polluted water cannot enter inside the tube well.

2. Boiling of floodwater before use.

3. Use alum or purifying tablet with floodwater before use.
4. Conservation of drinking water in a large pot (Pitch, bottle, container etc.)

5. Repairing and disinfecting the damaged tube well and water supply option through community participation.

6. Excavation of ponds after disaster for salinity removal.

Table 1. Drinking water supply sources (present, past and during AILA) in the selected study area.

\begin{tabular}{|c|c|c|c|c|c|}
\hline SL NO & Question & Drinking Water Sources Base & I on Respondent percepti & $n(\%)$ & \\
\hline 01 & $\begin{array}{l}\text { What are the drinking } \\
\text { water sources at present }\end{array}$ & Pond $n=58,(48 \%)$ & Tube well n=39, (33\%) & $\begin{array}{l}\text { Rain water Harvesting } \\
n=5,(4 \%)\end{array}$ & $\begin{array}{l}\text { Pond Sand Filters } \\
\text { (PSF) } n=18,(15 \%)\end{array}$ \\
\hline 02 & $\begin{array}{l}\text { What was the drinking } \\
\text { water sources in past }\end{array}$ & Pond $n=89,(74 \%)$ & Tube well $n=31,(26 \%)$ & & \\
\hline 03 & $\begin{array}{l}\text { What was the drinking } \\
\text { water sources during AILA }\end{array}$ & $\begin{array}{l}\text { NGO/ Voluntary Organization } \\
\text { Supply Water } n=71,(59 \%)\end{array}$ & $\begin{array}{l}\text { Neighbor's Village } \\
\mathrm{n}=33,(28 \%)\end{array}$ & $\begin{array}{l}\text { Used Affected Water } \\
\text { Sources } n=16,(13 \%)\end{array}$ & \\
\hline
\end{tabular}

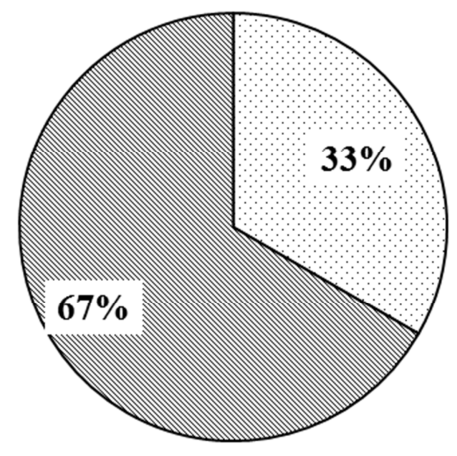

$\square$ Sufficient (Never faced drinking water scarcity)

$\mathbb{\mathbb { N }}$ Not sufficient (Faced drinking water scarcity)

Figure 2. Sufficiency of drinking water during disasters.

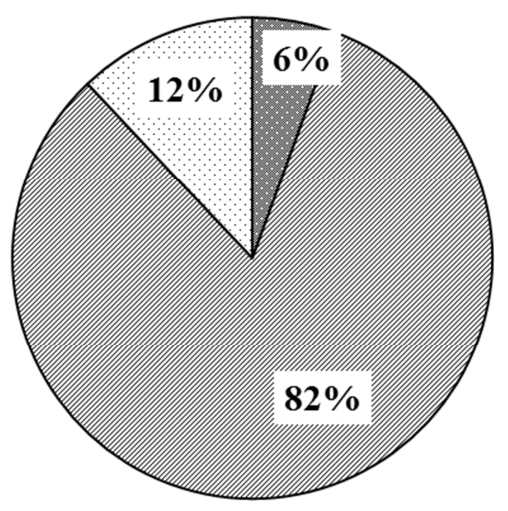

$\square$ Septic tank

Ring-slab

๑Hanging

\subsection{Impact on Sanitation}

Sanitation generally refers to the provision of facilities and services for the safe disposal of human urine and feces. The UNESCO defines sanitation as 'Maintaining clean, hygienic circumstances that help avoid disease through services such as waste collection and waste water removal'. Since last one decade this situation has been improved with the Government's ambitious target of "Sanitation for all by 2010". A Study conducted by WHO and UNICEF in 2004 (cited in [21]) estimated the sanitation coverage of Bangladesh and found that 39 percentage for rural and 75 percentage of urban population through Government claims better achievement. The sanitation situation in the coastal region is different from other parts of the country. Many of the rural Communities far away from 100 per cent sanitation coverage. Shymnagur upazilla is one of the rural areas where sanitation condition is poor. From the field survey, it has been found that $82 \%$ used ring slab toilet (Toilet was constructed by clay with one slab and two or three concrete rings), $12 \%$ hanging and 6\% septic tank (Fig. 3).

Figure 3. Present toilet types in the selected study area.

Table 2. Sanitation status (before and during Cyclone AILA) in the selected study area.

\begin{tabular}{|c|c|c|c|c|c|c|}
\hline SL NO & Question & $\begin{array}{l}\text { Respondent } \\
\text { perception (\%) }\end{array}$ & Sanitation types (\%) & the selected study area & & \\
\hline 01 & $\begin{array}{l}\text { How many and which types } \\
\text { of sanitation systems were } \\
\text { usable before AILA }\end{array}$ & $\begin{array}{l}\text { Fully usable } \\
n=120,(100 \%)\end{array}$ & $\begin{array}{l}\text { Ring slab } n=86, \\
(72 \%)\end{array}$ & $\begin{array}{l}\text { Concrete based Septic } \\
\text { tank } n=10,(8 \%)\end{array}$ & $\begin{array}{l}\text { Hanging toilet } \\
\mathrm{n}=24,(20 \%)\end{array}$ & \\
\hline 02 & $\begin{array}{l}\text { How many and which types } \\
\text { of sanitation systems were } \\
\text { used during AILA }\end{array}$ & $\begin{array}{l}\text { Partially } \\
\text { Damaged Toilet } \\
n=3,(3 \%) \\
\text { Fully Damaged } \\
\text { Toilet } n=117 \text {, } \\
(97 \%)\end{array}$ & $\begin{array}{l}\text { Concrete based Septic } \\
\text { tank } n=3,(3 \%) \\
\text { Open Defecation } \\
n=41,(34 \%)\end{array}$ & $\begin{array}{l}\text { Hanging Toilet } n=36 \text {, } \\
(30 \%)\end{array}$ & $\begin{array}{l}\text { Defecation into } \\
\text { the water by boat } \\
n=30,(25 \%)\end{array}$ & $\begin{array}{l}\text { Used neighbor } \\
\text { toilet jointly } \\
n=10,(8 \%)\end{array}$ \\
\hline
\end{tabular}

These study areas also represent that 97\% household toilets were fully damaged and 3\% were partially damaged by cyclone AILA (presented in Table - 2.) the main causes behind these problems were

- Inundation of toilet due to flood.

- Latrines fill-up due to water level rise. 
- Infrastructure damage due to erosion.

- Infrastructure collapse due to cyclone.

Due to the destruction of sanitation facilities people need to change their defecation practices during cyclone AILA. Some people practiced defecation openly, some were used boat, some people used temporary built hanging latrines which were connected water bodies and the rest of them used neighbors latrines jointly during theses time vulnerable groups (Women's, Children's and Old peoples) faces serious problems $[22,23]$. In the study area, it has been noticed that during cyclone AILA sanitation practices were 34\% open defection, 30\% hanging toilet, $25 \%$ used boat and $8 \%$ used neighbor's toilet jointly (Presented in Table - 2). From the field survey report, it has been observed that about $96 \%$ household in the study area cannot use their toilet during flood (Fig. 4) because most of the toilets are not disaster sustainable sanitation system.

\subsubsection{Adaptation Measure Regarding Sanitation}

Since most of the toilet in the study area was becoming unusable during disaster, so people can take some adaptation measure to minimize the problem.

- Raising the base of the toilet.

- Installation of toilet far away from water body.

- Immediately after a disaster people need to defecate in a proper manner in the absence of sanitary facilities, e.g., covering excreta with soil or sand after defecation and no defecation on any open water bodies.

- Increasing the base height of the toilet using more than one sanitary ring, which raise the height of the toilet about $1.5 \mathrm{ft}$.

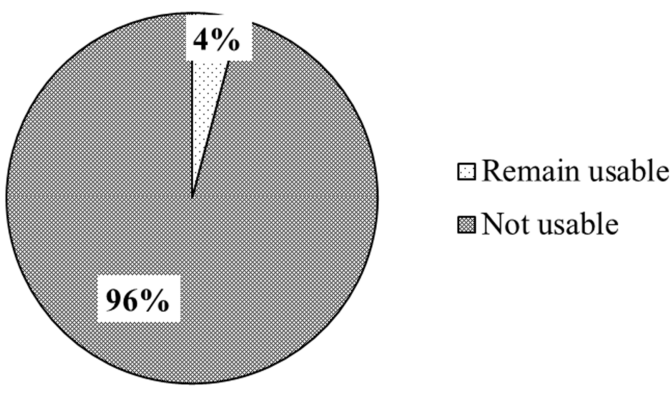

Figure 4. Precipitation of respondents on present toilets during flood time use.

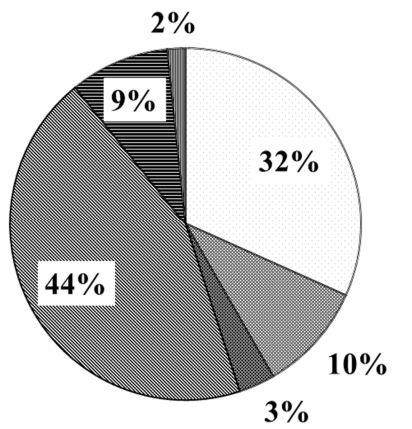

$\square$ Diarrhoea

- Fever

Pain

$\mathbb{Q}$ Dysentry

严 Sun-stroke

m Malaria

Figure 5. Present diseases pattern in the selected study area.

\subsection{Impact on Health}

Health is an important factor in terms of development. But the poor people of Bangladesh are affected now and then by natural hazards or disasters. Lack of proper sanitation facilities, drinking water and lack of awareness about hygiene lead to various types of health hazards. According to the report by UNICEF 1999 (cited in [24]), diarrhoea and dysentery continue to be the major causes of sickness and 15 percentages of all deaths in Bangladesh due to poor water supply sanitation facilities. From the field investigation, it has been observed that diarrhoea (46\%) and dysentery $(30 \%)$ was the main diseases during disaster among the households because all of the water supply and sanitation facilities have been disrupted. Though various types of NGOs and voluntary organization were trying to supply drinking water, but it was not sufficient for all of them, so they used pollute water for drinking, washing and bathing purpose. The Household also claimed that they were affected by skin disease (13\%), fever (9\%) and cold and cough (4\%) in most of the disaster time. About $68 \%$ household reported that their health care complex is far from their house, it may be $8-10 \mathrm{~km}$. As a result, they suffer most during disaster in case of emergency treatment due to the communication disruption. Some respondent said that Supply of medicines with other stuffs remains stopped during that time, so their suffering level has been increased. Scarcity of medicine, lack of treatment cost and other important materials is also responsible for deteriorating the scenario. According to reference [25], about 55,282 people who got injured during the cyclone may cause further deterioration in the health sector if they do not have proper treatment facilities. The tendency of diarrhoea (32\%) and dysentery (44\%) is high in the study area because the majority percentage used pond water as their main drinking water sources without any further treatment and poor sanitation system. Besides, people also suffered from fever $(10 \%)$, sun-stoke $(9 \%)$, pain $(3 \%)$ and malaria $(2 \%)$ due to seasonal climate change (Fig.5).

\subsubsection{Adaptation Regarding Water Borne Diseases}

Adaptations regarding water borne diseases are:

- During disaster people can use water supply and sanitation facilities in cyclone shelters.

- Store any type of emergency medicine, such as oral saline, pain killer, first aid etc. for preventing health problems.

- Collect water from neighboring areas that are less affected by floods and where a tube-well is located at a higher altitude.

- Keep sanitation system clean.

- Keep latrine at least 10 meters away from the tube well.

\section{Conclusion}

Every year different types of disaster cause huge damages of assets, environment, daily life and livelihood and put people in great distress. Surface water sources such as ponds, channels were flooded by polluted water, thus creating 
useless and tube well in the affected areas also inundated by the flood water, resulting in saline water intrusion in the well pipe thereby ceasing supply of potable water. Pond Sand Filters (PSF) also badly damaged. As ponds were the main drinking water sources in the study area as a result, they suffer most during a disaster. At present time most of the pond are dried during summer, it creates water scarcity and the majority of the household reported that they feel it during that time. In the coastal region most rural people use ring slab toilet these latrines are generally fragile and set up on low grounds; they collapse easily and it also inundated by flood water and they could not use it during flood time. It leaves people no other options but to go for open defecation. So the overall environmental situation was deteriorating through pollution of water by human excreta. Due to using polluted water and living in unsanitary conditions people suffering from various types of water borne diseases. At present the number of diarrhoea and dysentery diseases are highest among the households. Due to communication disruption and long distance from household to health care center, people faced serious problem for emergency treatment during disaster. Peoples in the study area take temporary adaptation measure; but they do not do anything that will support them during next disasters. This study proposed some adaptation measure that will be very helpful for them to combat in future. Engaging academic institutes, engineers approach, government and non government organization in order to developing sustainable water supply and sanitation fcailities.

\section{References}

[1] DoE, "Climate change and Bangladesh," Climate Change Cell. Department of Environment. Government of the People's Republic of Bangladesh. Dhaka, 2007.

[2] Bangladesh Bureau of Statistics (BBS), Government People's Republic of Bangladesh. Dhaka. Bangladesh, 1999.

[3] K. Roy, U. Kumar, H. Mehedi, T. Sultana and D. M. Ershad, "Initial Assessment Report with focus on Khulna District," Unnayan Onneshan.Humanitywatch.Nijera Kori. Khulna .Bangladesh, 2009.

[4] A. U. Ahmed and N. Haque, "Climate Change and Sustainable Development. Paper presented at the Dhaka Meet on Sustainable Development," Incorporated in Q. K. Ahmad and A. U. Ahmed (eds.). Citizens' Perspectives on Sustainable Development. Bangladesh Unnayan Parishad (BUP), 2002.

[5] S. Agrawala, T. Ota, A. U. Ahmed, J. Smith and M. V. Aalst, "Development and climate change in Bangladesh: Focus on coastal flooding and the Sundarbans," Report no.: COM/ENV/EPOC/DCD/DAC(2003)3/FINAL. Paris: OECD, 2009.

[6] A. Rahman, and M. Alam, "Mainstreaming Adaptation to Climate Change in Least Developed Countries (LDCs)," Bangladesh Country Case Study. IIED Working Paper, 2003.

[7] D. A. Mooley, "Severe cyclonic storms in the Bay of Bengal 1877-1977,” Mon Weather Rev. 108, pp1647-1655, 1980.

[8] C. E. Haque, "Hazards in a fickle environment. Bangladesh".
Kluwer. The Netherlands, 1997.

[9] T. S. Murty, and V. R. Neralla, "On the recurvature of tropical cyclones and the storm surge problem in Bangladesh," Nat Hazards 6(3), pp275-279, 2011.

[10] K. B. Bangladesh WASH, "Learning and Knowledge Sharing Workshop on Response to Cyclone Aila in Khulna. Water Aid in Bangladesh, 09-10 December 2009.

[11] National Food Policy Capacity Strengthening Programme (NFPCSP) Workshop on, "Research to Inform Food and Nutrition Security Policies," Compendium of Inception and Interim Reports. Safety net and Migration (Session III), Volume 2, Dhaka, 7- 8 May 2012.

[12] UN Joint Aila Assessment Mission, "Joint UN Multi Sector Assessment \& Response Framework of Cyclone AILA," 2010, available at

https://www.google.com.bd/url?sa=t\&rct=j\&q=\&esrc=s\&sour ce $=$ web \&cd $=1 \&$ cad $=$ rja\&uact $=8 \&$ ved $=0$ CCEQFjAA\&url $=$ htt p\%3A\%2F\%2Fwww.lcgbangladesh.org\%2Fderweb\%2FNeed s\%2520Assessment\%2FReports\%2FAila_UN_AssessmentFra mework_FINAL.pdf\&ei=i7n1VOymF4PmsATd34LQCQ\&us $\mathrm{g}=\mathrm{AFQjCNG8HDLWrRyzjvw2TsK1Qp9fXxWymQ \& bvm=bv}$ .87269000, d.cWc (Accessed on 3rd May 2015).

[13] A. Mahmood, "Flood impacts on rural water supply and sanitation and mitigation options," Proceedings of the National Workshop on Options for Flood Risk and Damage Reduction in Bangladesh. Dhaka, 7-9 September 2004.

[14] DMB-GoB, "National plan for disaster management 2010 2015," Disaster management bureau. Disaster management and relief division. Government of Bangladesh, 2010.

[15] CRF, "Living with cyclone Aila," Coastal Research Foundation. Khulna, 2010.

[16] Bangladesh Population Census, "Cultural survey report of Shyamnagar Upazila," Bangladesh Bureau of Statistics. Dhaka. Bangladesh, 2001.

[17] World Health Organization, "An Interview with Mahmudur Rahman Bangladesh's arsenic agony," Bulletin of the World Health Organization (BLT), Vol. 86 1, pp. 11-12, 25th April 2008, available at www.who.int/hac/techguidance/ems/flood_cds/en/print.html (accessed 3rd February 2015).

[18] S .N. Mclean, and D. R. Moore, "A mitigation strategy for the natural disaster of poverty in Bangladesh," Disaster prevention and Management, Vol. 14. No. 2, pp. 223-6, 2005.

[19] F. Sayeeda, "Suitability Of Pond Sand Filters As Safe Drinking Water Solution In Storm Surge Prone Areas Of Bangladesh: A Case Study Of Post-Aila Situation In Shyamnagar, Satkhira District, Khulna," Master's thesis paper. BRAC University. Dhaka. Bangladesh, 2011.

[20] N. Hafizi, "Unnecessary and Deadly: The Post-Disaster Catastrophe of Waterborne Diseases," Retrieved January 5th 2012. from The Triple Helix Online: http://triplehelixblog.com/2011/03/unnecessary-and-deadlythe-post-disaster-catastrophe-of-waterborne-diseases, March 2011.

[21] UNDP, "Bangladesh Rural Sanitation Supply Chain and Employment Impact", Human Development Report 2006. 2006/43. United Nations Development Programs. New York. NY, 2006. 
[22] A. C. Shimi, G. A. Parvin, C. Biswas and R. Shaw, "Impact and adaptation to flood A focus on water supply, sanitation and health problems of rural community in Bangladesh," Emerald Group Publishing Limited 0965-3562. Disaster Prevention and Management Vol. 19. No. 3, pp. 298-313, 2010.

[23] Z. Hussain, S. T. Islam, M. R. Amin, S. Hussain, S. Naznin, S. M. S. Islam and M. H. Shsihir, "Handbook on Climate Change and Disaster Resilient Water, Sanitation and Hygiene Practices," WaterAid in Bangladesh. ISBN: 978-984-33-80203, 2012.
[24] M. Galway, "New approaches to promoting sanitation in rural Bangladesh," Sanitation and Hygiene Promotion Series, Water and Sanitation Program - South Asia, New Delhi, Vol. 2, 2000 .

[25] Ministry of Food and Disaster Management, "Impacts and Strategies for Interventions”, Super Cyclone Sidr, p. 20, 2007. 